\title{
Subcellular Fractionation of Candida boidinii after Growth on Glucose or Methanol
}

\author{
By RICHARD O. JENKINS, ${ }^{1}$ TREVOR G. CARTLEDGE, ${ }^{1 *}$ AND \\ DAVID LLOYD² \\ 'Department of Life Sciences, Trent Polytechnic, Nottingham NGI 4BU, UK \\ 2 Department of Microbiology, University College, Newport Road, Cardiff, CFI 3NR, UK
}

(Received 22 May 1984; revised 17 July 1984)

\begin{abstract}
Extracts of glucose-grown and methanol-grown Candida boidinii were fractionated on sucrose gradients. Mitochondria and microbodies from methanol-grown cells were more fragile than those from glucose-grown cells. Formaldehyde and formate dehydrogenases and antimycin Ainsensitive NADPH:cytochrome $c$ oxidoreductase were non-sedimentable enzymes. The mitochondrial zone defined by cytochrome $c$ oxidase $\left(\rho=1.19\right.$ to $\left.1.20 \mathrm{~g} \mathrm{ml}^{-1}\right)$ contained sedimentable activities of malate dehydrogenase and citrate synthase. The vacuolar enzyme acid phosphatase was also recovered from this region. The microbody enzyme catalase sedimented to a lower density $\left(\rho=1.17 \mathrm{~g} \mathrm{ml}^{-1}\right)$ than mitochondria after growth on glucose but, together with methanol oxidase activity, to higher densities $\left(\rho=1.23\right.$ and $\left.1.27 \mathrm{~g} \mathrm{ml}^{-1}\right)$ after growth on methanol. Activity of the methanol assimilation enzyme dihydroxyacetone synthase was partially sedimentable and was recovered in the fraction containing mitochondria and membraneous vesicles. Inosine diphosphatase was probably multilocational in the cells.
\end{abstract}

\section{INTRODUCTION}

Growth of various yeasts on methanol is accompanied by increased development of microbodies (van Dijken et al., 1975a; Sahm et al., 1975; Tanaka et al., 1976). These organelles are involved in the initial oxidative metabolism of methanol and are also termed peroxisomes (van Dijken et al., 1975a, b; Fukui et al., 1975; Roggenkamp et al., 1975; Veenhuis et al., 1976). Microbodies of glucose-grown cells are smaller and fewer in number (van Dijken et al., 1975a; Tanaka $e t$ al., 1976) and have no readily asssignable specialized function, although in Hansenula polymorpha they are thought to develop into peroxisomes during growth on methanol (Veenhuis et al., 1979) or on other substrates (Zwart et al., 1983).

Despite a wealth of publications on activities, cytology and histochemistry of microbodies after growth on methanol (e.g. Tsubouchi et al., 1976; Meisel et al., 1978; Veenhuis et al., 1981) there have been few reports on subcellular fractionation of methanol-grown yeasts, although enzymes involved with methanol dissimilation are thought to have different subcellular locations. After either sucrose or Ficoll density gradient fractionation of Candida boidinii, alcohol oxidase and catalase are recovered from heavy microbody-enriched fractions (Fukui $e t$ al., 1975; Roggenkamp et al., 1975). Differential centrifugation of cell extracts has shown that formaldehyde and formate dehydrogenases are probably soluble enzymes (Fukui et al., 1975; Sahm et al., 1975; Tanaka et al., 1976). No systematic study has been made of the subcellular localization of the enzymes involved in the assimilation of methanol and there are no reports on subcellular fractionation of methylotrophic yeasts after growth on glucose.

This paper presents, for the first time, detailed high resolution fractionations using sucrose density gradients of cell extracts of Candida boidinii. In addition, the influence of growth substrate on the subcellular distribution of organelles in these gradients is discussed.

Abbreciation: DHA, dihydroxyacetone. 


\section{METHODS}

Maintenance and growth. Candida boidinii CBS 2428 was maintained on potato dextrose agar slopes. The medium of Veenhuis et al. (1976) was used for growth, except that yeast extract was added to $0.025 \%$. Glucose or methanol was added at $0.8 \%(\mathrm{w} / \mathrm{v})$ or $1.0 \%(\mathrm{w} / \mathrm{v})$, respectively. Cultures were grown and organisms counted as described previously (Jenkins et al., 1983). Mean generation times in exponential phase of growth on glucose and methanol were 1.55 and $3.47 \mathrm{~h}$, respectively; cell concentrations in stationary phase were $1.6 \times 10^{8}$ and $2.6 \times 10^{7}$ cells $\mathrm{ml}^{-1}$, respectively. Cultures were harvested at $3.0 \times 10^{7}$ organisms $\mathrm{ml}^{-1}$ for glucose-grown cells and $1.0 \times 10^{7}$ organisms $\mathrm{ml}^{-1}$ for methanol-grown cells

Harvesting, preparation and disruption of spheroplasts. All centrifugation procedures were carried out at $4{ }^{\circ} \mathrm{C}$ except during harvesting of cells, when a temperature of $30^{\circ} \mathrm{C}$ was maintained. Organisms were harvested by centrifugation at $6000 \mathrm{~g}$ in a $6 \times 250 \mathrm{ml}$ rotor of an MSE 18 centrifuge. Spheroplasts were prepared using zymolyase (Kogoya Co., Tokyo, Japan), as described previously (Jenkins et al., 1983). Preparation of cell extract was as described previously (Jenkins et al., 1983) using a spheroplast disruption buffer containing $0.25 \mathrm{M}$-sucrose, $2 \mathrm{mM}-\mathrm{MgCl}_{2}$ and $10 \mathrm{mM}$-Tris $/ \mathrm{HCl}(\mathrm{pH} \mathrm{7.4})$. In studies involving assays for dihydroxyacetone (DHA) synthase, the disruption buffer also contained $0.5 \mathrm{~mm}$-thiamin pyrophosphate, $1 \mathrm{~mm}-\mathrm{DTT}$ and $0.024 \%$ phenylmethanesulphonyl fluoride. In some instances, disruption buffers containing 0.4 or $0.9 \mathrm{M}$-sucrose, sorbitol $(0.25,0.4,0.65$ or $0.9 \mathrm{M}$ ), or mannitol $(0.25,0.4$ or $0.9 \mathrm{M})$ in place of $0.25 \mathrm{M}$-sucrose were used and centrifugation was adjusted to ensure removal of whole cells and intact spheroplasts.

Fractionation of cell extract by differential and zonal centrifugation. Differential centrifugations were carried out in an $8 \times 50 \mathrm{ml}$ rotor of an MSE 18 centrifuge at $20000 \mathrm{~g}$ for $20 \mathrm{~min}$, as described previously (Jenkins et al., 1983). Zonal centrifugations were carried out in a BXIV aluminium rotor of an MSE 50 Superspeed centrifuge at $25000 \mathrm{~g}$ for $236 \mathrm{~min}$. Fractionations through sucrose gradients were performed by the method of Cartledge \& Lloyd (1972), except that for methanol-grown cells gradient construction included $40 \mathrm{ml}$ of $52 \%(\mathrm{w} / \mathrm{w})$ sucrose, and $0.5 \mathrm{~mm}$ thiamin pyrophosphate, $1 \mathrm{mM}$-DTT and $0.024 \%$ phenylmethanesulphonyl fluoride were incorporated throughout the gradient.

Enzyme assays. The following assays were carried out by previously published methods : citrate synthase (EC 4.1.3.7) (Srere et al., 1963); catalase (EC 1.11.1.6) (Luck, 1963); formaldehyde dehydrogenase (EC 1.2.1.1) (Rose \& Racker, 1966); formate dehydrogenase (EC 1.2.1.2) (Quayle, 1966); NADPH:cytochrome $c$ oxidoreductase (EC 1.6.2.4) (Duppel et al., 1973) in the presence of $10 \mu \mathrm{g}$ antimycin A; acid $p$-nitrophenyl phosphatase (EC 3.1.3.2) and alkaline p-nitrophenyl phosphatase (EC 3.1.3.1) (Torriani, 1960); methanol oxidase (EC 1.1.3.13) (Borman \& Sahm, 1978). DHA synthase was assayed by two methods. (1) By measuring the xylulose 5-phosphate-dependent rate of removal of formaldehyde (discontinuous assay; Waites \& Quayle, 1980). (2) By measuring the rate of NADH oxidation due to formaldehyde and xylulose 5-phosphate-dependent formation of triose phosphates (continuous assay; Waites \& Quayle, 1981). Malate dehydrogenase (EC 1.1.1.37) was assayed as described by Kitto (1969) except that $0.1 \mathrm{M}$-potassium phosphate buffer, pH 7.8, was used. Cytochrome $c$ oxidase (EC 1.9.3.1) was assayed as described by Smith (1955), except that cytochrome $c$ was previously reduced with dithionite and passed through a G25 Sephadex column. Inosine diphosphatase (EC 3.6.1.6) was assayed according to Delaissé et al. (1981), except that 2 mM-inosine 5 'diphosphate was used.

Triton X-100 (final concentration $0 \cdot 01 \%$ ) was added to enzyme mixtures for cytochrome $c$ oxidase, malate dehydrogenase and citrate synthase. Acid and alkaline phosphatase assays were carried out in the presence of $0.2 \%$ Triton X-100. Various concentrations of this reagent were shown not to increase the detectable activities of any of the remaining enzymes assayed and were therefore excluded from these enzyme assays. Inosine diphosphatase was assayed after rapid freezing and thawing of samples.

Preliminary experiments were carried out with cell extracts to ensure that the enzyme activities were proportional to the amount of extract protein used and were not limited by substrate concentration. Where necessary, appropriate dilutions of cell extracts and fractions were used to obtain a suitable enzyme rate.

Electron microscopy. Electron micrographs were prepared as described by Jenkins et al. (1983).

Analytical methods and chemicals. Protein was estimated by the Lowry method using bovine serum albumin as standard. Ingredients of enzyme assays were obtained from Sigma, except 2,2'-azino-di-[3-ethyl-benzthiazoline sulphonate (6)] and a mixture of triose phosphate isomerase and glycerol-3-phosphate dehydrogenase which were obtained from Boehringer. Formaldehyde was prepared from an aqueous suspension of paraformaldehyde by heating in a sealed ampoule at $110^{\circ} \mathrm{C}$ for $20 \mathrm{~h}$.

\section{RESULTS}

\section{Differential centrifugation of cell extracts}

Whereas cytochrome $c$ oxidase activity was virtually all sedimentable in extracts from both glucose-grown and methanol-grown cells, high percentage sedimentabilities of malate dehydrogenase and catalase were obtained only for extracts of glucose-grown cells (Table 1). 
Table 1. Sedimentability of selected enzymes in cell extracts

Sedimentability was calculated as a percentage of the total recovered activity present in the pellet formed following centrifugation at $20000 \mathrm{~g}$ for $20 \mathrm{~min}$. The values presented are mean results of at least five experiments. Recoveries of enzyme activity were between 85 and $105 \%$.

$\begin{array}{lcc} & \overbrace{\text { Glucose-grown }} & \text { Methanol-grown } \\ \text { Cytochrome } c \text { oxidase } & 100 & 98 \\ \text { Malate dehydrogenase } & 91 & 46 \\ \text { Catalase } & 70 & 29 \\ \text { Methanol oxidase } & \text { ND } & 80\end{array}$

ND, Not detectable.

Methanol oxidase activity, detectable only after growth on methanol, was largely sedimentable (Table 1).

Solubilization of catalase during incubation of methanol-grown cells with zymolyase was low, representing less than $4 \%$ of the total non-sedimentable catalase obtained following disruption of harvested spheroplasts in $0.2 \mathrm{M}$-potassium phosphate buffer, $\mathrm{pH} 7.4$.

In an attempt to increase the percentage sedimentabilities of catalase and malate dehydrogenase in extracts from methanol-grown cells, alterations were made to the osmotic stabilizer in the spheroplast disruption buffer. Improved sedimentabilities of catalase and malate dehydrogenase ( 34 and $54 \%$, respectively) were obtained only when using a disruption buffer containing $0.9 \mathrm{M}$-sorbitol in place of $0.25 \mathrm{M}$-sucrose. However, disruption of spheroplasts in $0.9 \mathrm{M}$-sorbitol was poor and activities of enzymes in these extracts were 70 to $80 \%$ lower than those in extracts prepared using $0.25 \mathrm{M}$-sucrose. Prolonged homogenization of spheroplasts in $0.9 \mathrm{M}$-sorbitol lowered the percentage sedimentabilities of catalase and malate dehydrogenase in cell extracts.

\section{Zonal centrifugation of an extract from glucose-grown cells}

Profiles of optical density at $260 \mathrm{~nm}$ and $520 \mathrm{~nm}$ showed major peaks at $\rho=1 \cdot 10 \mathrm{~g} \mathrm{ml}^{-1}$ and $\rho=1.19 \mathrm{~g} \mathrm{ml}^{-1}$, respectively (Fig. $1 a$ ). Some protein was recovered at these densities but the majority $(52 \%)$ remained in the region of the sample zone (Fig. 1a). This region also contained virtually all alkaline phosphatase activity (Fig. $1 b$ ), all formaldehyde dehydrogenase (Fig. $1 d$ ) and antimycin A-insensitive NADPH:cytochrome $c$ oxidoreductase (Fig. $1 e$ ) activities and non-sedimentable activities of the other enzymes assayed. Acid phosphatase activity (Fig. $1 b$ ) was $32 \%$ sedimentable, located in a zone containing all cytochrome $c$ oxidase (Fig. $1 c$ ) and greater than $90 \%$ of the activities of malate dehydrogenase and citrate synthase (Fig. $1 \mathrm{c}$ ). Peak activities of enzymes in this zone were at $\rho=1.19 \mathrm{~g} \mathrm{ml}^{-1}$, corresponding with maximum optical density at $520 \mathrm{~nm}$. Sedimentable catalase activity $(58 \%)$ was distributed broadly over densities of 1.15 to $1.25 \mathrm{~g} \mathrm{ml}^{-1}$ (Fig. $1 d$ ), but the peak of this activity was found at a lower density $(\rho=$ $1.17 \mathrm{~g} \mathrm{ml}^{-1}$ ) than that of cytochrome $c$ oxidase. The distribution of inosine diphosphatase (Fig. $1 e$ ) was complex, with most activity recovered over densities of $\rho=1.07$ to $1.12 \mathrm{~g} \mathrm{ml}^{-1}$ and remaining activity distributed between the sample zone and a zone at $\rho=1.20 \mathrm{~g} \mathrm{ml}^{-1}$.

Activities of methanol oxidase and formate dehydrogenase were non-detectable in this cell extract.

\section{Zonal centrifugation of an extract from methanol-grown cells}

Sucrose gradient fractionation in a tube $(23 \mathrm{ml})$ showed that sedimentable activities of cytochrome $c$ oxidase and methanol oxidase are distributed mainly over densities of 1.20 to $1.27 \mathrm{~g} \mathrm{ml}^{-1}$ (data not shown). In order to attempt to improve separation of organelles over these densities, a shallower region was incorporated into the gradient at a density of $1.24 \mathrm{~g} \mathrm{ml}^{-1}$ and fractionation was carried out using the zonal rotor. 


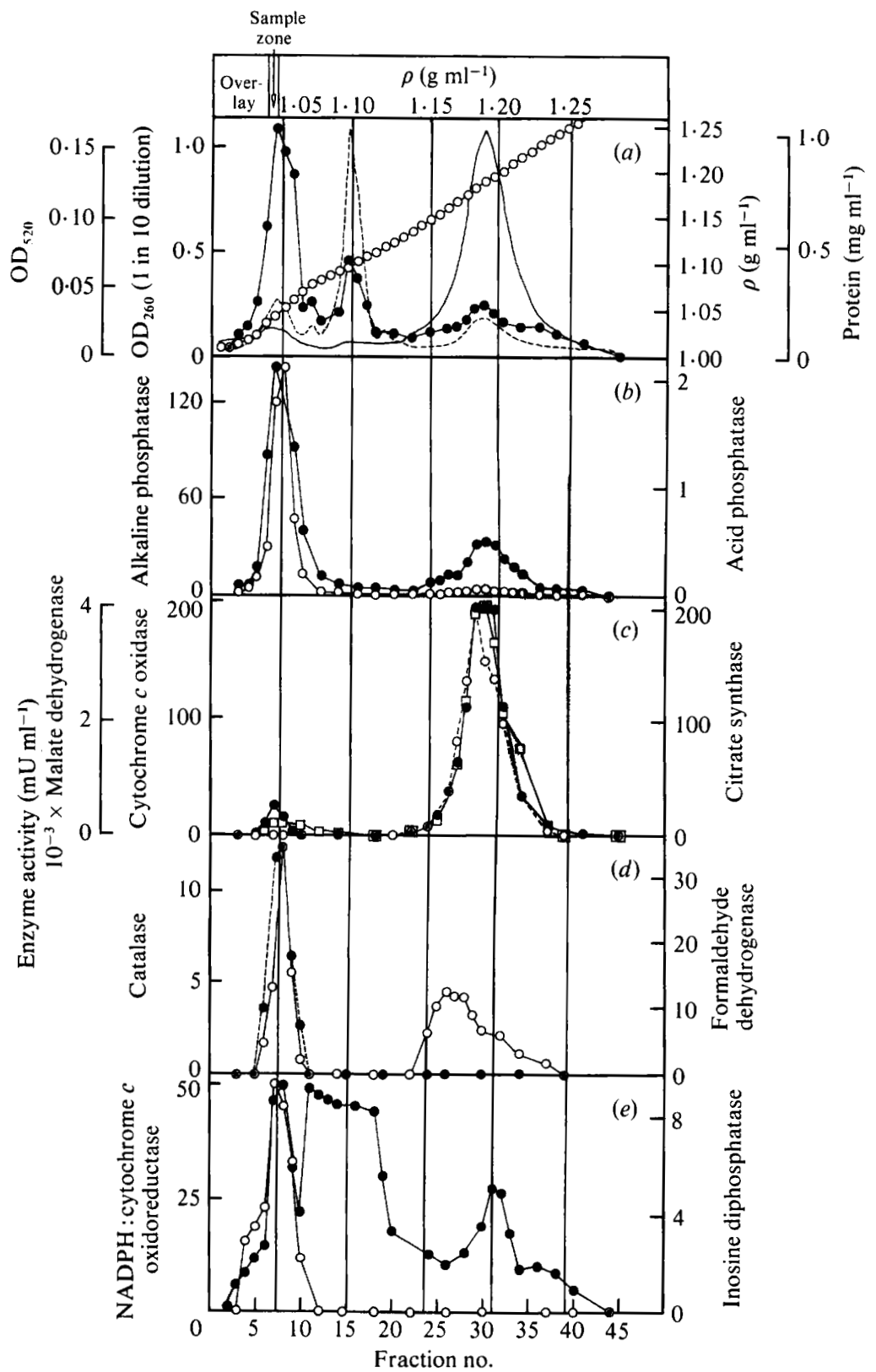

Fig. 1. Zonal centrifugation of a cell extract from glucose-grown $C$. boidinii on a sucrose gradient. Cell extract $(10 \mathrm{ml})$ containing $63 \mathrm{mg}$ of protein was loaded on the gradient. Centrifugation was at 28000 r.p.m. for $236 \min \left(6 \times 10^{6} \mathrm{~g}\right.$-min at the sample zone: $\left.\int_{0}^{t} \omega^{2} . \mathrm{d} t=1.45 \times 10^{11} \mathrm{rad}^{2} \mathrm{~s}^{-1}\right)$. Enzyme activities shown on the ordinates are $\mathrm{mU} \mathrm{ml}^{-1}$, where one unit represents $1 \mu \mathrm{mol}$ substrate used or product formed $\mathrm{min}^{-1}$. Where indicated in the text percentage sedimentability refers to the amount of enzyme activity detected beyond $\rho=1.10 \mathrm{~g} \mathrm{ml}^{-1}$. (a) Sucrose density gradient $(O), \mathrm{OD}_{520}(-)$ measured using an SP1800, $\mathrm{OD}_{260}(--)$ and protein $(O)$. (b) Alkaline phosphatase $(O)$ and acid phosphatase (O). (c) Cytochrome $c$ oxidase (O), malate dehydrogenase $(O)$ and citrate synthase $(\square)$. (d) Catalase (O) and formaldehyde dehydrogenase (O). (e) Antimycin A-insensitive NADPH: cytochrome $c$ oxidoreductase $(O)$ and inosine diphosphatase $(O)$. Specific activities $[\mathrm{mU}(\mathrm{mg}$ protein $)^{-1}$ ] of enzymes in the cell extract were as follows (recoveries in parentheses): protein $(115 \%)$; alkaline phosphatase, $87(74 \%)$; acid phosphatase, $1.9(108 \%)$; cytochrome $c$ oxidase, $238(68 \%)$; malate dehydrogenase, $3900(101 \%)$; citrate synthase, $202(98 \%)$; catalase, $11(92 \%)$; formaldehyde dehydrogenase, $21(78 \%)$; antimycin A-insensitive NADPH : cytochrome $c$ oxidoreductase, $52(62 \%)$; inosine diphosphatase, $26(98 \%)$. 
The main peak of optical density at $260 \mathrm{~nm}$ was located at $\rho=1.07 \mathrm{~g} \mathrm{ml}^{-1}$ (Fig. 2a). Profile of optical density at $520 \mathrm{~nm}$ clearly defined two regions of the gradient: maximum OD at $\rho=$ $1.20 \mathrm{~g} \mathrm{ml}^{-1}$ and a further peak at $\rho=1.27 \mathrm{~g} \mathrm{ml}^{-1}$ (Fig. $2 a$ ). Sedimentable protein $(42 \%$ ) was broadly distributed over densities of 1.15 to $1.27 \mathrm{~g} \mathrm{ml}^{-1}$ (Fig. $2 a$ ). Non-sedimentable protein was almost entirely located in the sample zone. The region of the sample zone contained virtually all alkaline phosphatase activity (Fig. $2 b$ ) and all of the activities of antimycin A-insensitive NADPH : cytochrome $c$ oxidoreductase (Fig. 2e) and formaldehyde and formate dehydrogenases (Fig. 2f). Most if not all of the non-sedimentable activities of the other enzymes assayed were also recovered from this region. The sedimentable portion of acid phosphatase activity $(59 \%)$ was greater than that obtained for the extract from glucose-grown cells. The peak of this activity was located at a marginally higher density of $\rho=1.20 \mathrm{~g} \mathrm{ml}^{-1}$ (Fig. $2 b$ ), corresponding with the maximum optical density at $520 \mathrm{~nm}$. All cytochrome $c$ oxidase and sedimentable citrate synthase $(66 \%)$ formed almost identical symmetrical zones of activity (Fig. $2 c$ ) with peak activites at $\rho=1.20 \mathrm{~g} \mathrm{ml}^{-1}$. Sedimentable activities of malate dehydrogenase $(48 \%$; Fig. $2 c)$ and DHA synthase ( 23 to $33 \%$; Fig. $2 e$ ) were also recovered from this region. An electron micrograph of this region of the gradient (Fig. $3 a$ ) shows the presence of mitochondria and small membraneous vesicles. Similar distributions of the latter enzyme were obtained by continuous and discontinuous assays and satisfactory recoveries of activity were obtained. An electron micrograph of the region at $\rho=1.23 \mathrm{~g} \mathrm{~m}^{-1}$ (Fig. $3 b$ ) indicates the presence of mitochondria, microbodies and membraneous vesicles while the region at $\rho=1.27 \mathrm{~g} \mathrm{ml}^{-1}$ contains microbodies and little other membraneous material (Fig. $3 c$ ). Sedimentable activities of catalase $(19 \%)$ and methanol oxidase ( $88 \%$ ) formed similar bimodal distributions (Fig. $2 d$ ), with distinct peaks of activity located at $\rho=1.23 \mathrm{~g} \mathrm{ml}^{-1}$ and $1.27 \mathrm{~g} \mathrm{ml}^{-1}$, the latter corresponding with a maximum optical density at $520 \mathrm{~nm}$. Inosine diphosphatase (Fig. $2 e$ ) was recovered largely from the sample zone although a peak of activity at $\rho=1.07 \mathrm{~g} \mathrm{ml}^{-1}$, corresponded with the maximum of optical density at $260 \mathrm{~nm}$. Sedimentable activities of this enzyme $(30 \%)$ showed a broad density distribution with a small peak at $\rho=1.23 \mathrm{~g} \mathrm{ml}^{-1}$.

\section{DISCUSSION}

The oxidative metabolism of methanol to $\mathrm{CO}_{2}$ is indicated by the high specific activities of methanol oxidase, catalase, formaldehyde dehydrogenase and formate dehydrogenase in extracts from methanol-grown cells. The comparatively low or non-detectable activities of these enzymes in extracts from glucose-grown cells probably reflects control of their synthesis by catabolite repression-derepression (Egli et al., 1980).

Decreased sedimentability of catalase and possibly malate dehydrogenase in extracts from methanol-grown relative to glucose-grown cells indicates increased fragility of organelles. This hypothesis is supported by cytochemical evidence that catalase is located solely within microbodies of methanol-grown yeast (van Dijken et al., 1975b; unpublished data from our laboratory). Gross solubilization of catalase during spheroplast formation was not apparent and changes made to the osmolarity of the spheroplast disruption buffer had little effect on sedimentability of enzymes. The results of Fukui et al. (1975) show that the activities of both catalase and methanol oxidase are largely non-sedimentable after disruption of spheroplasts of methanol-grown $C$. boidinii in $0.65 \mathrm{M}$-sorbitol. Our results show that in $0.25 \mathrm{M}$-sucrose, high percentage sedimentability of methanol oxidase but not catalase can be achieved. The organization of these enzymes within microbodies (Veenhuis et al., 1981) probably accounts for their difference in sedimentability: whereas catalase was shown to be largely a matrix enzyme, methanol oxidase was a structural element of the crystalline core.

After fractionation of extracts from either glucose or methanol-grown cells a number of distinct zones on sucrose gradients can be characterized.

Non-sedimentable enzyme activities recovered from the proximity of the sample zone may reflect a truly cytosolic location for the enzymes and/or loss of enzymes from membraneous organelles. The presence of all recovered activities of formate and formaldehyde dehydrogenases and antimycin A-insensitive NADPH : cytochrome $c$ oxidoreductase in this region favours 


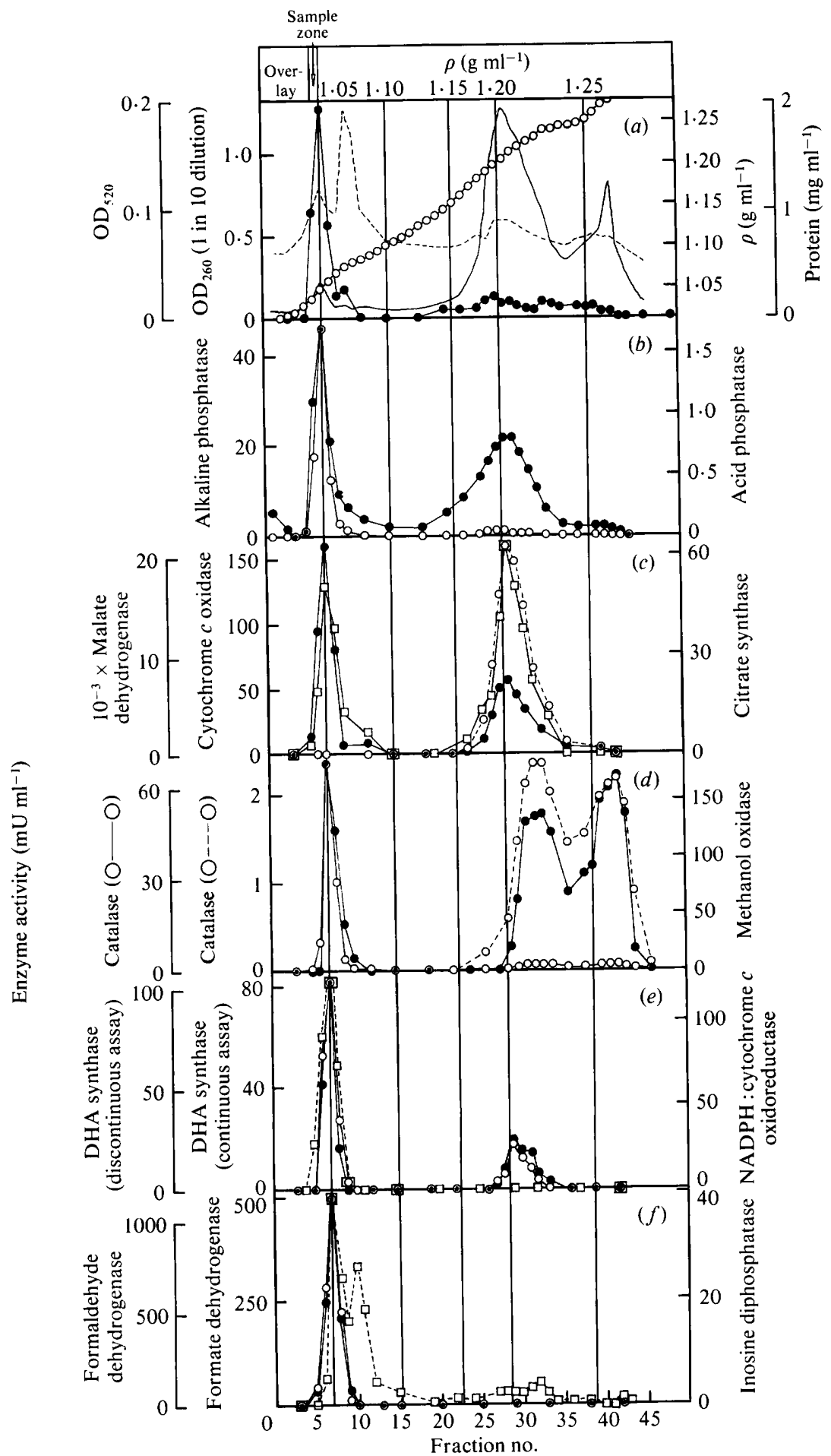

Fig. 2. Zonal centrifugation of a cell extract from methanol-grown $C$. boidinii on a sucrose gradient. Cell extract $(10 \mathrm{ml})$ containing $78 \mathrm{mg}$ of protein was loaded on the gradient. Centrifugation was at 28000 r.p.m. for $236 \mathrm{~min}\left(6 \times 10^{6} \mathrm{~g}\right.$-min at the sample zone; $\left.\int_{0}^{t} \omega^{2} . \mathrm{d} t=1.45 \times 10^{11} \mathrm{rad}^{2} \mathrm{~s}^{-1}\right)$. Enzyme activities shown on the ordinates are $\mathrm{mU} \mathrm{ml}^{-1}$, where one unit represents $1 \mu \mathrm{mol}$ substrate used or product formed $\mathrm{min}^{-1}$. Where indicated in the text percentage sedimentability refers to the amount of 
the first possibility. A cytosolic localization for the first two enzymes confirms the findings of other workers (Fukui et al., 1975; Sahm et al., 1975; Tanaka et al., 1976) and for the last enzyme indicates that it is not a suitable microsomal marker for this organism as suggested by Cartledge \& Lloyd (1972) in Saccharomyces carlsbergensis.

The mitochondrial zone, characterized by cytochrome $c$ oxidase activity, was readily identified and contained all the sedimentable activities of malate dehydrogenase and citrate synthase. Increased sedimentable activities of citrate synthase, and possibly malate dehydrogenase, after fractionation of methanol-grown cells relative to glucose-grown cells presumably indicates differences in fragility of mitochondria. For both fractionations the sedimentable activity of acid phosphatase, an enzyme characteristically associated with yeast vacuoles, was also recovered from the mitochondrial zone. After similar fractionations using metrizamide gradients this activity was well separated from cytochrome $c$ oxidase activity (R. O. Jenkins, unpublished results).

After fractionation of glucose-grown cells, the microbody region, as defined by sedimentable catalase activity, was found at a lower density $\left(\rho=1.17 \mathrm{~g} \mathrm{ml}^{-1}\right)$ than the region containing mitochondria. After fractionation of methanol-grown $C$. boidinii, Fukui et al. (1975) reported microbodies as heavier than mitochondria in sucrose. Whilst our results agree with this finding they also show that after growth on methanol two microbody zones at densities of 1.23 and $1.27 \mathrm{~g} \mathrm{ml}^{-1}$ can be distinguished using a zonal rotor, as opposed to the single broad density region distinguished by these workers using a small volume $(15 \mathrm{ml})$ tube gradient. The localization of methanol oxidase within these zones (both of which contain intact microbodies, as confirmed electron microscopically) allows the term peroxisome, defined by Tolbert $\&$ Essner (1981), to be assigned to associated organelles. Whether the observed heterogeneity represents two functionally distinct classes of peroxisomes in $C$. boidinii or arises from damage during isolation and separation requires further investigation.

Activity of DHA synthase, a key methanol assimilation enzyme (O'Connor \& Quayle, 1980; Waites \& Quayle, 1980), was partially sedimentable and was recovered in the fraction containing mitochondria and membraneous vesicles. Sedimentable activity is difficult to explain as other enzymes involved in methanol assimilation, for example fructose-1,6bisphosphatase, have been shown cytochemically to be in the cytosol (Veenhuis et al., 1980). Both continuous and discontinuous assays for DHA synthase gave very similar results and all relevant precautions (Waites \& Quayle, 1980, 1981) to measure only DHA synthase activity and eliminate any enzymes such as transketolase, alcohol dehydrogenases and formaldehyde oxidase were carefully carried out.

Inosine diphosphatase appears to be multilocational in these cells. The recovery of large portions of this enzyme's activity at low densities distinct from the sample zone indicates that the occurrence of inosine diphosphatase in unidentified small membraneous vesicles, as reported by Delaissé et al. (1981) for Saccharomycopsis lipolytica, must be considered.

The results presented here show that the distribution of organelles on sucrose gradient can be markedly influenced by the nature of the growth substrate. After growth on methanol, a

enzyme activity detected beyond $\rho=1 \cdot 10 \mathrm{~g} \mathrm{ml}^{-1}$. (a) Sucrose density gradient $(\mathrm{O}), \mathrm{OD}_{520}(-)$ measured using an SP1800, $\mathrm{OD}_{260}(--)$, protein $(O)$. (b) Alkaline phosphatase $(O)$ and acid phosphatase (O). (c) Cytochrome $c$ oxidase $(O)$, malate dehydrogenase $(\boldsymbol{O})$ and citrate synthase $(\square)$. (d) Catalase (O), catalase (sedimented activity only; $\mathrm{O}_{--O}$ ) and methanol oxidase (O). (e) DHA synthase (continuous assay; $O$ ), DHA synthase (discontinuous assay; $O$ ) and antimycin A-insensitive NADPH:cytochrome $c$ oxidoreductase $(\square)$. ( $f$ ) Formate dehydrogenase $(O)$, formaldehyde dehydrogenase $(\bigcirc)$ and inosine diphosphatase $(\square)$. Specific activity [mU(mg protein $\left.)^{-1}\right]$ of enzymes in the cell extract were as follows (recoveries in parentheses): protein $(107 \%)$; alkaline phosphatase, 12 $(105 \%)$; acid phosphatase, $2(68 \%)$; cytochrome $c$ oxidase, $97(117 \%)$; malate dehydrogenase, 12860 $(98 \%)$; citrate synthase, $65(89 \%)$; catalase, $974(65 \%)$; methanol oxidase, $207(121 \%)$; DHA synthase (continuous assay), $27(103 \%)$; DHA synthase (discontinuous assay), $35(96 \%)$; antimycin A-insensitive NADPH : cytochrome $c$ oxidoreductase, $52(78 \%)$; formate dehydrogenase, $142(96 \%)$; formaldehyde dehydrogenase, $325(91 \%)$; inosine diphosphatase, $26(92 \%)$. 

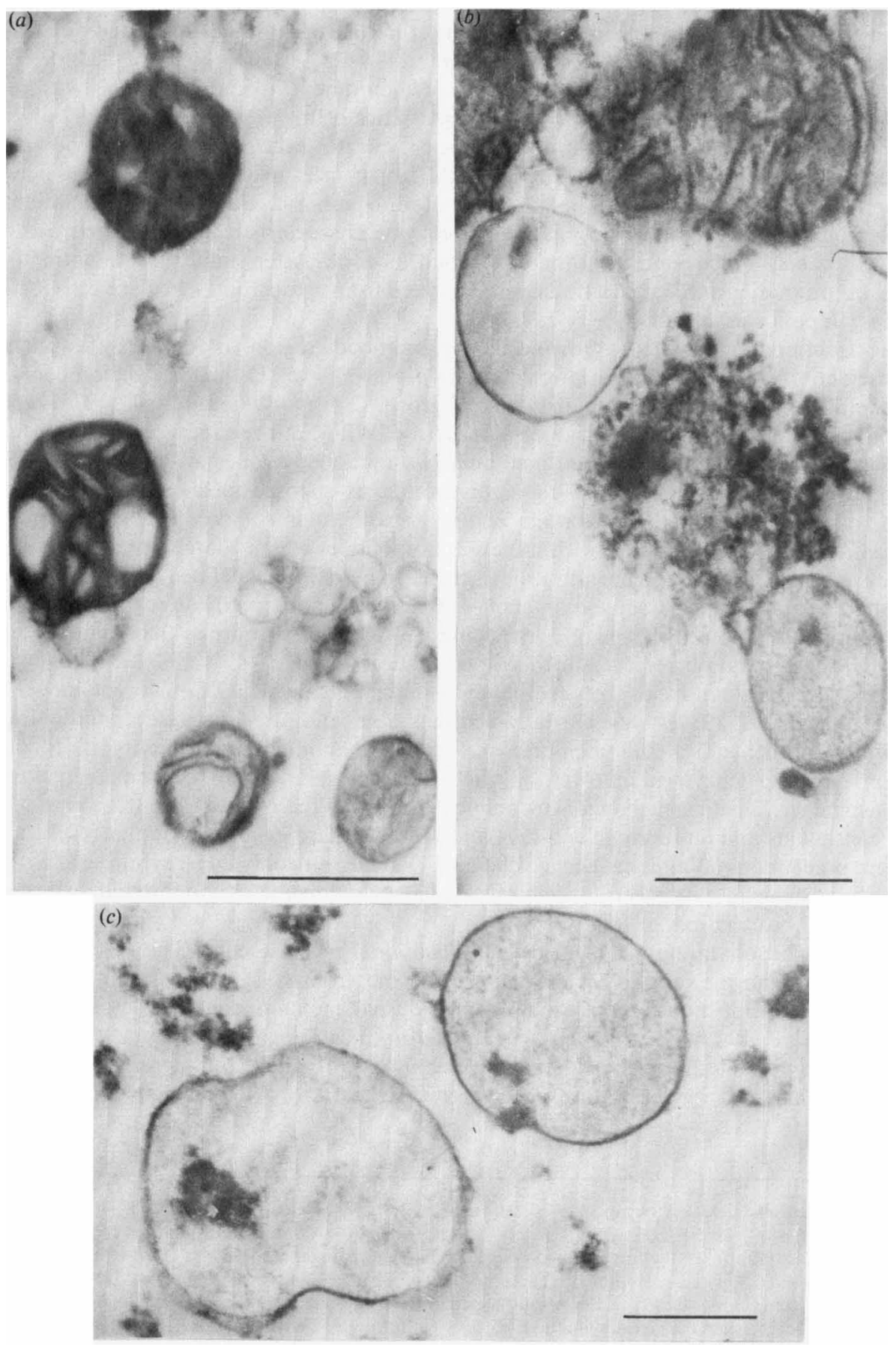

Fig. 3. Electron micrographs of section of material from experiment shown in Fig. 2. (a) Fraction 29 , (b) fraction $32,(c)$ fraction 43 . Bar markers, $0.5 \mu \mathrm{m}$. 
heterogeneous population of microbodies may be present in the cell, although possible diversity of function has yet to be established. Further work is also required to clarify the localization of enzymes involved in methanol assimilation.

We thank Mr D. Lacey for assistance during preparation of electron micrographs and Mrs P. Horne for occasional technical assistance.

\section{REFERENCES}

BormanN, C. \& SAHM, H. (1978). Degradation of microbodies in relation to activities of alcohol oxidase and catalase in Candida boidinii. Archives of Microbiology 117, 67-72.

Cartledge, T. G. \& Lloyd, D. (1972). Subcellular fractionation by differential and zonal centrifugation of aerobically grown derepressed Saccharomyces carlsbergensis. Biochemical Journal 126, 381-393.

Delaissé, J. M., Martin, P., Verheyen-Bouvy, M. G. \& NYNS, E. J. (1981). Subcellular distribution of enzymes in the yeast Saccharomycopsis lipolytica grown on $n$-hexadecane, with special reference to $\omega$ hydroxylase. Biochimica et biophysica acta 676, 7790.

van Dijken, J. P., Veenhuis, M., Kreger-Van Rij, N. J. W. \& HARDER, W. (1975a). Microbodies in methanol assimilating yeasts. Archives of Microbiology 102, $41-44$.

van Dijken, J. P., Veenhuis, M., Vermeulen, C. A. \& HARDER, W. (1975b). Cytochemical localization of catalase activity in methanol-grown Hansenula polymorpha. Archices of Microbiology 105, 261-267.

Duppel, W., Lebeault, J. M. \& CoOn, M. J. (1973). Properties of a yeast cytochrome P-450 containing enzyme system which catalyses the hydroxylation of fatty-acids, alkanes and drugs. European Journal of Biochemistry 36, 583-592.

Egli, Th., van Dijken, J. P., Veenhuis, M., Harder, W. \& FilCHTER, A. (1980). Methanol metabolism in yeasts: regulation of the synthesis of catabolic enzymes. Archives of Microbiology 124, 115-121.

Fukui, S., Kawamoto, S., Yasuhara, S., Tanaka, A., Osumi, M. \& ImaIzUmi, F. (1975). Microbodies of methanol-grown yeasts. Localization of catalase and flavin-dependent alcohol oxidase in the isolated microbody. European Journal of Biochemistry 59 , $561-566$

Jenkins, R. O., Cartledge, T. G. \& Lloyd, D. (1983). Subcellular fractionation of Candida stellatoidea after growth with glucose or $n$-hexadecane. Journal of General Microbiology 129, 1171-1185.

KitTo, G. B. (1969). Intra- and extra-mitochondrial malate dehydrogenase from chicken and tuna heart. Methods in Enzlmolog. 13, 106-116.

LcCK, H. (1963). Catalase. In Methods of Enzymatic Analysis, vol. 2, pp. 885-900. Edited by H. V. Bergmeyer. New York: Academic Press.

Meisel, M. N., Mededeva, G. A., Kozlova, T. M., Pomoshchnikova, N. A. \& Novichkova, A. T. (1978). Formation and degradation of peroxisomes in yeast organisms. Mikrobiologiya 47, 10301036.

O'Connor, M. L. \& Quayle, J. R. (1980). Pentose phosphate-dependent fixation of formaldehyde by methanol-grown Hansenula polymorpha and Candida boidinii. Journal of General Microbiology 120, 219 225.
Quayle, J. R. (1966). Formate dehydrogenase. Methods in Enzymology 9, 360-364.

Roggenkamp, R., SaHM, H., Hinkelmann, W. \& WAGNER, F. (1975). Alcohol oxidase and catalase in peroxisomes of methanol-grown Candida boidinii. European Journal of Biochemistry 59, 231-236.

Rose, Z. B. \& RACKer, E. (1966). Formaldehyde dehydrogenase. Methods in Enzymology 9, 357-360.

Sahm, H., Roggenkamp, R., Wagner, F. \& HinkelMANN, W. (1975). Microbodies in methanol-grown Candida boidinii. Journal of General Microbiology 88 , 218-222.

SmITH, L. (1955). Cytochromes $a, a_{1}, a_{2}$ and $a_{3}$. Methods in Enzymology 2, 736-740.

Srere, P. A., Brazil, H. \& Goren, L. (1963). The citrate condensing enzyme of pigeon breast muscle and moth flight muscle. Acta chemica scandinavica 17, S129-S134.

Tanaka, A., Yasuhara, S., Kawamoto, S., Fukui, S. \& OsumI, M. (1976). Development of microbodies in the yeast Kloeckera growing on methanol. Journal of Bacteriology 126, 919-927.

Tolbert, N. E. \& Essner, E. (1981). Microbodies: peroxisomes and glyoxisomes. The Journal of Cell Biology 91, 271s-283s.

TorRIANI, A. (1960). Influence of inorganic phosphate in the formation of phosphatases by Escherichia coli. Biochimica et biophysica acta 38, 460-469.

Tsubouchi, J., Tanomura, K. \& TanaKa, K. (1976). Ultrastructure of microbodies of methanol-assimilating yeasts. Journal of General and Applied Microbiology 22, 131-142.

Veenhuis, M., van Dijken, J. P. \& Harder, W. (1976). Cytochemical studies on the localization of methanol oxidase and other oxidases in peroxisomes of methanol-grown Hansenula polymorpha. Archices of Microbiology' 111, 123-135.

Veenhuis, M., KeIZer, I. \& HaRder, W. (1979). Characterization of peroxisomes in glucose-grown Hansenula polymorpha and their development after the transfer of cells into methanol-containing media. Archices of Microbiology 120, 165-175.

Veenhuis, M., van Dijken, J. P. \& Harder, W. (1980). A new method for the cytochemical demonstration of phosphatase activities in yeasts based on the use of cerous ions. FEMS Microbiology Letters 9 , 285291.

Veenhuis, M., Harder, W., van DiJken, J. P. \& MAYER, F. (1981). Substructure of crystalline peroxisomes in methanol-grown Hansenula polymorpha: evidence for an in rivo crystal of alcohol oxidase. Molecular and Cellular Biology 1, 949-957.

Waites, M. J. \& Quayle, J. R. (1980). Dihydroxyacetone: a product of xylulose 5-phosphate-dependent fixation of formaldehyde by methanol-grown Candida boidinii. Journal of General Microbiology 118 , $321-327$. 
Waites, M. J. \& Quayle, J. R. (1981). The interrelation between transketolase and dihydroxyacetone synthase activities in the methylotrophic yeast Candida boidinii. Journal of General Microbiology 124, 309-316.
Zwart, K. B., Veenhuis, M., Plat, G. \& Harder, W. (1983). Characterization of glyoxysomes in yeasts and their transformation into peroxisomes in response to changes in environmental conditions. Archives of Microbiology 136, 28-38. 